\title{
A Study on the Preparation Method of Geopolymeric Concrete using Specifically Modified Silicate and Inorganic Binding Materials and Its Compressive Strength Characteristics
}

\author{
Jong Young Kim $* * * * * \dagger$ \\ *YOUNG IL CHEMICAL CO., LTD. Incheon 404-254, Korea \\ **Division of Business Administration, Graduate School of Soongsil University, Seoul 156-743, Korea \\ (Received February 10, 2015; Revised March 12, 2015; Accepted March 12, 2015)
}

\begin{abstract}
Recently, research on geopolymeric concrete that does not use cement as a binder has been actively investigated. Geopolymeric concrete is cement-free concrete. Masato, ocher and/or soil has been solidified into geopolymeric concrete by the reaction of specifically modified silicate as an alkali activator and inorganic binding materials such as blast furnace slag, fly ash or meta-kaolin, which is cured at room temperature to exhibit high compressive strengths. Based on the results, this study shows how geopolymeric concrete that uses specifically modified silicate and inorganic binding materials is implemented as eco-cement with no cement.
\end{abstract}

Key words : Geopolymeric concrete, Blast furnace slag, Fly ash, Meta kaolin, Specifically modified silicate, Water glass

\section{Introduction}

$\mathrm{A}^{\mathrm{s}}$ s the importance of earth environment preservation is gradually increased, efforts are being made for reduction of greenhouse gases as the main culprit of global warming. Since Portland cement used in large quantities in civil construction areas is produced by melting at a high temperature $\left(1450^{\circ} \mathrm{C}\right)$, causing emission of carbon dioxide as the main culprit for large amounts of energy consumption and greenhouse gases accounting for more than $7 \%$ of total emission of the greenhouse gases, the measures to limit its uses are under study. As a method of substituting for the use of such cement, studies on geopolymeric concrete are being actively conducted. ${ }^{1,2)}$ Geopolymeric concrete is a method for substitution of cement, and generates a network of polycondensation of Si-O-Al through activation of inorganic materials containing $\mathrm{Si}$ and $\mathrm{Al}$ by alkali cations. ${ }^{3-5)}$

Studied in the present study are preparation methods for geopolymeric concrete using modified water glass and inorganic binding materials, as well as compressive strength characteristics of geopolymeric concrete.

Normally, water glass (liquid-phase sodium silicate) is used as an alkali activator for geopolymeric concrete. The characteristics and uses of water glass are determined according to a ratio of silica $\left(\mathrm{SiO}_{2}\right)$ vs. alkali metal $\left(\mathrm{Na}_{2} \mathrm{O}\right)$ and its concentration. When the ratio of silica vs. alkali metal is 1 , crystal particles are generated in water glass,

${ }^{\dagger}$ Corresponding author: Jong Young Kim

E-mail : jykim@youngilchem.co.kr

Tel : +82-32-578-6700 Fax : +82-32-578-4828 while the viscosity becomes high and gelation when the ratio of silica vs. alkali metal is larger than 4 . Although general water glass is a hydrophilic and strong alkali aqueous solution and somewhat plays a role as an alkali activator, it is important to manufacture modified water glass optimized for useful geopolymeric concrete. Consequently, sodium silicate solution has been selected as an alkali activator, it is modified by varying its molar ratio and the modified water glass is suitable for the inorganic solidified with acceptable strengths. In addition, blast furnace slag, fly ash or metakaolin as inorganic binding materials has been selected and its mixing ration with masato, soil, ocher, etc. is determined. ${ }^{6,7)}$ The characteristics of geopolymeric concrete have been examined by analyzing compressive strengths resulting from several mixtures.

\section{Experimental Procedure}

\subsection{Modified water glass (Specifically modified sili- cate solution)}

The modified water glass used as an alkali activator in the present study more effectively decomposes the covalent bonds of $\mathrm{SiO}_{2}$ and $\mathrm{Al}_{2} \mathrm{O}_{3}$ in the inorganic materials and generate a geopolymeric matrix of $\mathrm{Al}-\mathrm{O}-\mathrm{Si}$ when the concentration of $\mathrm{OH}^{-}$is higher. For preparation of specifically modified silicate, sodium silicate solution No. 3KS (YOUNG IL CHEMICAL CO., LTD.) as the main material is used. $\mathrm{NaOH}$ is added into main material for changing the molar ration to $1 \pm 0.2$ then crystalline particles are generated. Sodium phosphate is added to this, it is combined with sodium silicate particles and flat into liquid. When it is mixed with 
heat, it is reverted to a liquid phase including no crystalline particles. The property of specifically modified silicate is shown in Table 1. The concentration of modified water glass is controlled by water. The prepared specifically modified silicate has $1.1 \sim 1.2$ of molar ratio of $\mathrm{SiO}_{2}$ to $\mathrm{Na}_{2} \mathrm{O}$ and $40 \%$ of concentration.

\subsection{Inorganic binding materials}

The inorganic binding materials used in the present study are by-products produced unavoidably at ironworks, refineries, power plants, etc. and they are made at very high temperature. These sellected materials can be used as inorganic binding materials for solidification of geopolymeric concrete. Blast furnace slag is produced at ironworks, fly ash is produced at power plants, and meta kaolin is produced at general producers. These materials contain silicon dioxide $\left(\mathrm{SiO}_{2}\right)$, aluminum oxide $\left(\mathrm{Al}_{2} \mathrm{O}_{3}\right)$, magnesium oxide $(\mathrm{MgO})$, calcium oxide $(\mathrm{CaO})$, etc., so selected materials can be used as inorganic binding materials to substitute for cement. Blast furnace slag, type 2 has the component ratio of $\mathrm{SiO}_{2}$
$33.5 \%, \mathrm{Al}_{2} \mathrm{O}_{3} 14.5 \%, \mathrm{CaO} 42.5 \%$. Fly ash has the component ratio of $\mathrm{SiO}_{2} 46.91 \%, \mathrm{Al}_{2} \mathrm{O}_{3} 44.47 \%, \mathrm{CaO} 0.53 \%$. Meta kaolin has the component ratio of $\mathrm{SiO}_{2} 52.6 \%, \mathrm{Al}_{2} \mathrm{O}_{3} 38.1 \%, \mathrm{CaO}$ $4.8 \%$. The component rations of each inorganic binding material are given in Table 2 .

\subsection{Solidified materials}

As the solidified materials for geopolymeric concrete in the present study, masato, ocher and soil are used. Chemical composition ratios of each material are shown in Table 3.

\subsection{Preparation of geopolymeric concrete}

Preparation method for geopolymeric concrete is shown in Fig. 1. For each material used for preparation of geopolymeric concrete, inorganic binding materials of blast furnace slag, fly Ash and meta kaolin are used, while masato, ocher and soil are used as solidified materials. For the role as an alkali activator, specifically modified water glass is used. In order to derive the optimum mixing ratio, the process of Fig. 1 is followed.

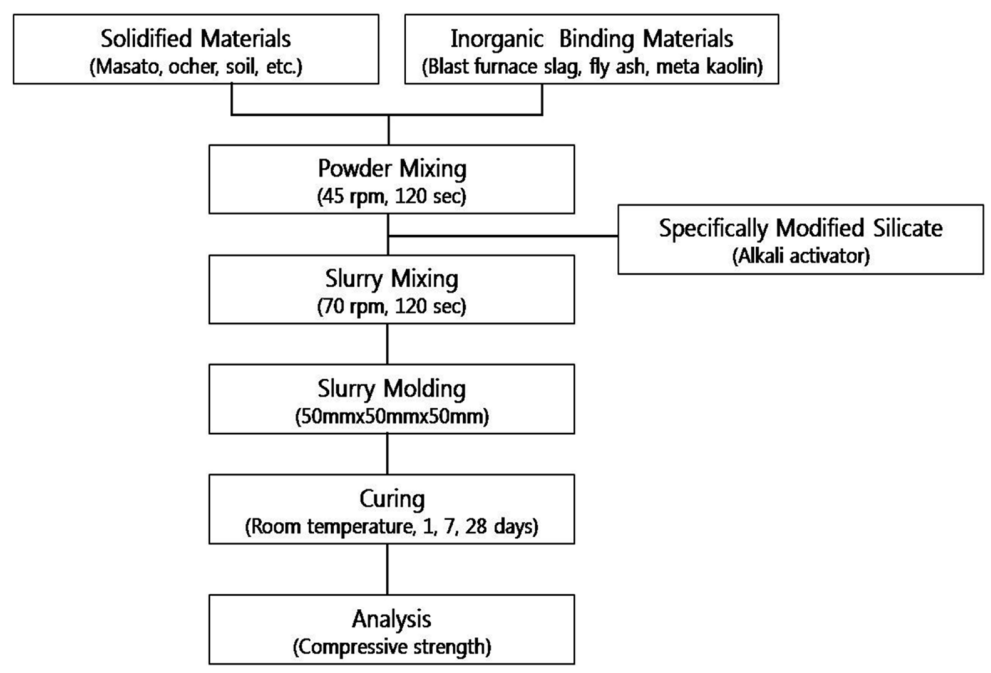

Fig. 1. Experimental process.

Table 1. Property of Specifically Modified Water Glass

\begin{tabular}{ccccc}
\hline Alkali activator & Appearance & Molar Ratio & $\mathrm{pH}$ & Concentration (\%) \\
\hline Specifically Modified Water Glass & Brown & $1.1 \sim 1.2$ & 12 & 40 \\
\hline
\end{tabular}

Table 2. Chemical Properties of Inorganic Binding Materials

\begin{tabular}{ccccccc}
\hline & $\mathrm{SiO}_{2}$ & $\mathrm{Al}_{2} \mathrm{O}_{3}$ & $\mathrm{CaO}$ & $\mathrm{MgO}$ & $\mathrm{Fe}_{2} \mathrm{O}_{3}$ & \multicolumn{2}{c}{ Surface $\operatorname{area}\left(\mathrm{cm}^{2} / \mathrm{g}\right)$} \\
\hline Blast furnace slag & 33.5 & 17.5 & 42.5 & 6 & 0.5 & 4,464 \\
Fly ash & 46.91 & 44.47 & 0.52 & 1.8 & 6.3 & 4,268 \\
Meta kaolin & 54.6 & 38.1 & 6.5 & 0.3 & 1.5 & 12,000 \\
\hline
\end{tabular}

Table 3. Chemical Properties of Solidified Materials

\begin{tabular}{ccccccc}
\hline & $\mathrm{SiO}_{2}$ & $\mathrm{Al}_{2} \mathrm{O}_{3}$ & $\mathrm{CaO}$ & $\mathrm{MgO}$ & $\mathrm{Fe}_{2} \mathrm{O}_{3}$ & Remarks \\
\hline General soil & 47.04 & 37.15 & 0.69 & 0.26 & 2.19 & Sedentary deposit \\
Masato & $50 \sim 60$ & $8 \sim 12$ & $4 \sim 16$ & $2 \sim 6$ & $2 \sim 4$ & Sedentary deposit \\
General ocher & 65 & 21.8 & 0.6 & 3 & 5.7 & Sedentary deposit \\
\hline
\end{tabular}


Table 4. Composition of Slurry Mixtures

\begin{tabular}{|c|c|c|c|c|c|c|c|c|c|}
\hline & $\begin{array}{l}\text { Blast furnace } \\
\text { slag }\end{array}$ & $\begin{array}{l}\text { Fly } \\
\text { Ash }\end{array}$ & Meta kaolin & Masato & $\begin{array}{c}\text { General } \\
\text { soil }\end{array}$ & Ocher & $\begin{array}{l}\text { Weight } \\
\text { (g) }\end{array}$ & $\begin{array}{l}\text { modified water } \\
\text { glass }(\mathrm{g})\end{array}$ & $\begin{array}{l}\text { Water } \\
\text { (g) }\end{array}$ \\
\hline $\mathrm{A}$ & 200 & & & 800 & & & 1000 & 140 & 70 \\
\hline B & 200 & & & & 800 & & 1000 & 140 & 70 \\
\hline $\mathrm{C}$ & 200 & & & & & 800 & 1000 & 140 & 70 \\
\hline D & & 200 & & 800 & & & 1000 & 140 & 70 \\
\hline $\mathrm{E}$ & & 200 & & & 800 & & 1000 & 140 & 70 \\
\hline $\mathrm{F}$ & & 200 & & & & 800 & 1000 & 140 & 70 \\
\hline G & & & 200 & 800 & & & 1000 & 140 & 80 \\
\hline $\mathrm{H}$ & & & 200 & & 800 & & 1000 & 140 & 80 \\
\hline I & & & 200 & & & 800 & 1000 & 140 & 80 \\
\hline
\end{tabular}

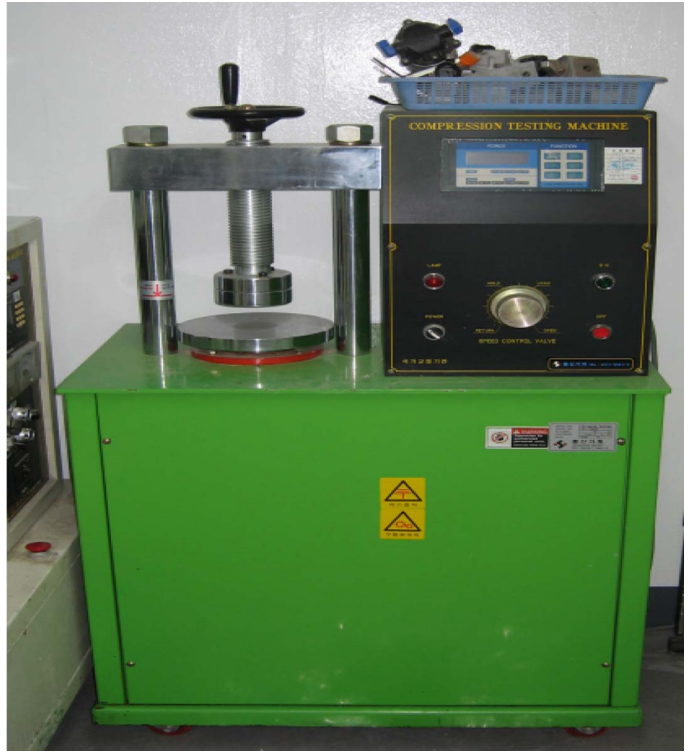

Fig. 2. Compressive strength testing machine.

First, solidified material and inorganic binding material are mixed for $120 \mathrm{sec}$ at a speed of $45 \mathrm{rpm}$ and then specifically modified water glass is added to the mixture and mixed for $120 \mathrm{sec}$ at a speed of $70 \mathrm{rpm}$. The compositions of slurry mixture are shown in Table 4 . To measure compressive strength of geopolymeric concrete, each slurry mixture is molded in the shape of $50 \mathrm{~mm} \times 50 \mathrm{~mm} \times 50 \mathrm{~mm}, \mathrm{KS} \mathrm{L}$ 5105 specification. Compressive strengths are measured using the compression strength apparatus of Fig. 2 (Compression tester ASH-100, Heung Shin Tester) after curing at room temperature for 1 day, 7 days, 28 days.

\section{Results and Discussion}

\subsection{Compressive strength}

In the present study, geopolymeric concrete was prepared according to the combinations of Table 4 and measurement results of compressive strength for each geopolymeric concrete are shown in Table 5.

For geopolymeric concrete $\mathrm{A} \sim \mathrm{C}$ using blast furnace slag
Table 5. Compressive Strength of Geopolymeric Concretes

\begin{tabular}{cccc}
\hline & \multicolumn{3}{c}{ Compressive Strength(MPa) } \\
\hline A & 1 day & 7 days & 28 days \\
B & 10.7 & 16.2 & 27.5 \\
C & 11.3 & 16.7 & 28.4 \\
D & 11.6 & 18.3 & 30.1 \\
E & 6.3 & 13.2 & 27.2 \\
F & 7.2 & 14.3 & 29.0 \\
G & 7.4 & 14.8 & 30.4 \\
H & 5.9 & 12.6 & 25.0 \\
I & 6.2 & 13.2 & 26.3 \\
\hline
\end{tabular}

as inorganic binding material, the compressive strength after 1 day is $10.7 \sim 11.6 \mathrm{MPa}$ and one after 28 days is raised to $27.5 \sim 30.1 \mathrm{Mpa}$. For geopolymeric concrete $\mathrm{D} \sim \mathrm{F}$ using fly ash as inorganic binding material, the compressive strength after 1 day is $6.3 \sim 7.4 \mathrm{MPa}$ and one after 28 days is raised to $27.2 \sim 30.4 \mathrm{Mpa}$. The compressive strength after 1 day in group $\mathrm{A} \sim \mathrm{C}$ is higher than ones in group $\mathrm{D} \sim \mathrm{F}$. The main reason is that $\mathrm{Ca}$ content of fly ash is less than one of blast furnace slag and the initial reactions of C-S-H in group D F are slow. The compressive strengths of group $\mathrm{D} \sim \mathrm{F}$ are raised to $82.5 \%$ of group $\mathrm{A} \sim \mathrm{C}$. This is considered that geopolymeric reaction of $\mathrm{M}-\mathrm{Si}-\mathrm{Al}^{8,9)}$ starts to contribute to increasing compressive strength. However, alkali exothermic reaction of $\mathrm{A} 1$ occurs and microcrack can be fined inside when more fly ash is added in slurry mixture. Therefore, a suitable amount of fly ash should be used. Although the results after 28 days of group $\mathrm{G} \sim \mathrm{I}$ using meta kaolin as inorganic binding material are the lowest among three groups, the increasing rate of the compressive strength is similar to that of group $\mathrm{D} \sim \mathrm{F}$. This is considered that the initial strengths are relatively low compared with group $\mathrm{A} \sim \mathrm{C}$ because low $\mathrm{Ca}$ content and later increased relatively faster than group $\mathrm{A} \sim \mathrm{C}$ because meta kaolin has a similar content of $\mathrm{SiO}_{2}+\mathrm{Al}_{2} \mathrm{O}_{3}$ to that of fly ash, which is higher than one of blast furnace slag. 


\section{Conclusion}

By preparing geopolymeric concretes with the mixtures of solidified material, inorganic binding material and specifically modified silicate, the following conclusion has been obtained. The reverential weight ratio of solidified material to inorganic binding material is 8 to 2 . Specifically modified silicate is added to this mixture for slurry mixture. Compressive strengths of geopolymeric concrete $\mathrm{C}, \mathrm{E}$ and $\mathrm{F}$ are excellent at 30.1, 29.0, 30.4 MPa. This is considered that the fineness of solidified material contributes to compressive strengths rather than inorganic binding materials.

For inorganic binding materials, blast furnace slag and fly ash showed similar strengths, and meta kaolin the lowest strength. In terms of initial strength, blast furnace slag showed excellent results, while fly ash showed an increase with curing. However, compressive strengths after 28 days are shown to be similar.

According to the results for compressive strengths, specifically modified water glass as alkali activator initially forms alumino-silicate gel and derives geopolymeric concrete reaction of M-Si-Al.

Therefore, geopolymeric concrete need to be developed for a substitution material for cement concrete and studied as eco-friendly studies for earth environment preservation.

\section{Acknowledgments}

The present study has been carried out as a development task project of YOUNG IL CHEMICAL CO., LTD., which is hereby appreciated.

\section{REFERENCES}

1. J. Davidovits, D. Comrie, and J. Paterson, "Geopolymeric Concretes for Environmental Protection," Concr, Int., 12 30-9 (1990)

2. W. Y. Lee, "The Improvement of Compressive Strength of Non-sintered Cement Mortar Alkali," J. Kor. Insti. Architectural, 10 670-77 (2006).

3. J. Temuujin, R. P. Williams, and A. van Riessen, "Effect of Mechanical Activation of Fly Ash on the Properties of Geopolymer Cured at Ambient Temperature," J. Mater. Proc. Technol., 8 48-56 (2009).

4. A. Palomo, "Alkali-activated Fly Ashes, a Cement for the Future," Cem. Concr. Res., 29 1323-29 (1999).

5. F. Paertas and A. Fernandez-Jimenez, "Mineralogical and Microstructural Characterisation of Alkali-activated Fly Ash/slag Pastes," Cement \& Concrete Composites, 25 85-91 (2003).

6. K. Ikeda, "Consolidation of Mineral Powders by the Geopolymer Binder Technique for Materials Use," Shigen-toSozai, 114 497-500 (1998).

7. P. Bankowski, L. Zou, and R. Hodges "Reduction of Metal Leaching in Brown Coal Fly Ash Using Goepolymer," J. Hazard. Mater., 114 59-67 (2004).

8. Y. Khalil and E. Merz "Immobilization of Intermedatelevel Waste in Geopolymers," J. Nucle. Mater., 211 141-48 (1994).

9. M. Minnarikova and F. Skvara "Fixztion of Heavy Metals in Geopolymeric Materials Based on Brown Coal Fly Ash," J. Nucle. Mater., 50 200-07 (2006). 